\title{
PERAN KOLESTEROL HDL TERHADAP PENYAKIT KARDIOVASKULER DAN DIABETES MELLITUS
}

Sulistyowati Tuminah ${ }^{1}$

${ }^{1}$ Puslitbang Biomedis dan Farmasi, Badan Litbangkes, Departemen Kesehatan RI

ABSTRACT

\section{ROLE OF HDL-CHOLESTEROL ON CARDIOVASCULAR DISEASE AND DIABETES MELLITUS}

Mortality in Indonesia which caused by cardiovascular disease showed an enhancing prevalent. One of the risk factors of cardiovascular disease is Dyslipidemia, marked by increasing on total, triglycerides and LDL but decreasing on HDL cholesterol. HDL cholesterol is a good cholesterol that has an important role in prevention of cardiovascular disease as well as diabetes mellitus. Two kinds of natural matters have known as elevator for HDL cholesterol are dark chocolate and virgin coconut oil.

Keywords: cardiovascular disease, HDL cholesterol, diabetes mellitus

\section{PENDAHULUAN}

D Indonesia, kematian karena penyakit tidak menular (PTM) tampak mengalami peningkatan dari tahun ke tahun jika dibandingkan dengan penyakit menular (PM) yang semakin menurun jumlahnya. Hal ini ditunjukkan dari hasil Survei Kesehatan Rumah Tangga (SKRT) 1995 dimana distribusi kematian akibat PM sebesar 44,2 persen dan PTM sebesar 41,7 persen. Pada SKRT 2001, kematian akibat PM mengalami penurunan menjadi 31,2 persen sementara kematian oleh PTM meningkat menjadi 49,9 persen. Sedangkan hasil Riset Kesehatan Dasar (Riskesdas) 2007, distribusi kematian karena PM menurun menjadi 28,1 persen sebaliknya kematian akibat PTM semakin meningkat menjadi 59,5 persen ${ }^{1}$.

Berdasarkan hasil Riskesdas 2007 diketahui bahwa proporsi terbesar penyebab kematian pada semua umur akibat PTM adalah penyakit Kardiovaskuler $(31,9 \%)$ termasuk di dalamnya stroke $(15,4 \%)$, hipertensi $(6,8 \%)$, penyakit jantung iskemik $(5,1 \%)$ serta penyakit jantung lainnya $(4,6 \%)$. Sedangkan proporsi kematian karena Diabetes Mellitus sebesar 5,7 persen, berada di peringkat ke-3 PTM penyebab kematian pada semua umur setelah Stroke dan Hipertensi ${ }^{1}$.

Salah satu faktor risiko utama penyakit kardiovaskuler adalah dislipidemia, yang merupakan kelainan metabolisme lipid. Dislipidemia ditandai dengan adanya peningkatan kadar kolesterol total, kolesterol LDL dan trigliserida serta penurunan kadar kolesterol HDL dalam darah. Kejadian dislipidemia di masyarakat semakin meningkat akibat perilaku yang cenderung mengkonsumsi makanan rendah serat dan tinggi lemak ${ }^{2}$. Dari laporan hasil penelitian MONICA tahun 2002, diperoleh hiperkolesterolemia > $250 \mathrm{mg} / \mathrm{dl}(27.7 \%), \geq$ $200 \mathrm{mg} / \mathrm{dl}(56.5 \%), \mathrm{HDL} \leq 40 \mathrm{mg} / \mathrm{dl}(47.3 \%)$, LDL $\geq 160 \mathrm{mg} / \mathrm{dl}$ (28.8\%), trigliserida $\geq 160$ $\mathrm{mg} / \mathrm{dl}(22.0 \%)$, serta rasio kolesterol total / $\mathrm{HDL} \geq 5(51.9 \%)^{3}$.

Selain itu, penyakit kardiovaskuler juga disebabkan oleh banyak faktor. Faktor yang telah diketahui berperan sebagai penyebab penyakit kardiovaskuler adalah 1). Asupan karbohidrat dengan indeks glisemik tinggi, 2). Homosistein, 3). C-reaktif protein, 4). Kurang olah raga, 5). Tekanan darah tinggi, 6). Keturunan, 7). Stres oksidatif, 8). Merokok, 9). Kegemukan, 10). Diabetes ${ }^{4}$.

Diabetes tipe 2 merupakan komponen pusat dari sindrom metabolik, yang terdiri dari suatu kumpulan faktor risiko penyakit 
arteri koroner yaitu diabetes tipe 2, obesitas abdominal, resisten insulin, hipertensi serta dislipoproteinemia dengan peningkatan konsentrasi triasilgliserol dan rendahnya konsentrasi kolesterol $\mathrm{HDL}^{5}$.

Tulisan ini bertujuan agar pembaca mengenal lebih jauh peranan kolesterol HDL dalam tubuh guna mencegah penyakit kardiovaskuler dan diabetes mellitus serta memahami apa akibat dari rendahnya kadar kolesterol HDL darah. Selain itu juga agar pembaca mengetahui contoh bahan alam yang dapat meningkatkan kolesterol HDL, sehingga tidak perlu mengkonsumsi obatobatan kimiawi yang dapat menimbulkan efek samping pada kesehatan.

\section{Kaitan antara Penyakit Kardiovaskuler dan Diabetes Mellitus}

Penyakit kardiovaskuler merupakan penyebab utama morbiditas dan mortalitas pada penderita diabetes mellitus tipe 2 . Diantara faktor-faktor risiko yang telah ditetapkan, profil lipid (tingginya kadar trigliserida, kadar small dense LDL, rendahnya kadar kolesterol HDL) adalah faktor risiko yang paling kuat untuk terjadinya aterosklerosis pada diabetes tipe 2 . Prevalensi hipertrigliseridemia pada diabetes tipe 2 adalah 2-3 kali lebih tinggi dibandingkan pada non-diabetes ${ }^{6}$.

Lipoprotein setelah makan secara khusus diperkirakan bersifat aterogenik. Metabolisme lipoprotein abnormal setelah makan umumnya ditemukan pada diabetes tipe 2. Oleh karena itu penderita diabetes tipe 2 mempunyai konsentrasi triasilgliserol setelah makan lebih tinggi daripada yang bukan penderita diabetes jika dibandingkan dengan konsentrasi triasilgliserol puasa. Konsekuensi dari berlebihnya triasilgliserol setelah makan adalah terbatasnya konsentrasi kolesterol HDL, yang berdampak pada peningkatan kesakitan akibat penyakit arteri koroner. Jadi korelasi negatif antara kolesterol HDL dan penyakit arteri koroner tampaknya berasal dari tingginya korelasi positif antara konsentrasi triasilgliserol setelah makan dengan penyakit arteri koroner $^{5}$.
Makanan yang mengandung karbohidrat dalam jumlah besar khususnya gula sederhana, juga dapat menyebabkan dislipidemia aterogenik karena pengaruhnya pada metabolisme plasma lipoprotein yang kaya akan triasilgliserol. Makanan berkarbohidrat tinggi, rendah lemak telah menunjukkan dapat memicu peningkatan konsentrasi LDL dan ekspresi fenotip partikel LDL dalam proporsi yang tinggi dari orangorang sehat. Dislipidemia aterogenik yang berkaitan dengan kelebihan jaringan lemak berhubungan erat dengan penurunan sensitivitas insulin ${ }^{7}$.

\section{Metabolisme dan Kerja Biologis Kolesterol HDL}

Kolesterol merupakan struktur lemak yang tidak dibutuhkan dalam makanan, karena dalam jumlah cukup telah disintesis oleh tubuh (hati dan usus). Kolesterol terdapat dalam makanan dan tubuh terutama sebagai kolesterol bebas atau sebagai ester dengan asam lemak ${ }^{8}$.

Kolesterol HDL berinteraksi dengan beberapa reseptor-reseptor seluler dan pengangkut-pengangkut lipid. Interaksi HDL atau apolipoprotein $\mathrm{A}-\mathrm{I}$ dengan penangkap reseptor $\mathrm{BI}$ atau adenosine trifosfat yang mengikat komponen pengangkut $A 1, G 1$ dan G4 memacu aliran kolesterol. Apolipoprotein dan enzim-enzim dibawa oleh fungsi oksidatif HDL. Beberapa modifikasi yang bersifat oksidatif dari apolipoprotein A-I, misalnya residu tirosin, dapat mengganggu aktivitas anti-aterosklerotik. Interaksi HDL dengan lisosfingolipid diidentifikasi sebagai pengaktivasi protein kinase Akt, yang secara bergantian merupakan pengatur apoptosis dalam sel-sel beta, endothelial dan sel-sel otot polos, juga sebagai pengatur produksi nitrat oksida dan ekspresi perlekatan molekul dalam sel-sel endothelial ${ }^{9,10}$.

Kolesterol HDL membantu proliferasi dan mengurangi pengguguran sel-sel endotel. HDL juga berperan penting dalam vasorelaksasi dengan meningkatkan pelepasan oksida nitrat dan prostasiklin melalui pemicuan ekspresi dan aktivitas dari sintesa oksida nitrat endotel. Selain itu, HDL berpengaruh pada koagulasi, fibrinolisis, 
perlekatan platelet, molekul-molekul yang berlekatan dan ekspresi protease. Hal tersebut mempengaruhi aktivitas antioksidan $^{11}$.

\section{Peran dan Fungsi HDL dalam Tubuh}

Kolesterol HDL berperan dalam membalikkan transpor kolesterol, yang memungkinkan organ hati untuk membuang kelebihan kolesterol dalam jaringan perifer. Proses pembalikkan transport kolesterol terdiri dari beberapa tahap, yaitu: aliran kolesterol dari membran sel menuju partikel penerima, esterifikasi dari kolesterol seluler oleh fosfatidilkolin-sterol O-asiltransferase (lesitin-kolesterol asiltransferase), transfer ester kolesterol ke partikel LD (low dense) atau VLD (very low dense) dengan dukungan protein transfer ester kolesterol, dan akhirnya mengantarkan ester kolesterol ke hati ${ }^{12}$.

Sifat protektif HDL terhadap produksi sitokin, oksidasi lipid, peningkatan kolesterol serta membalikkan transpor kolesterol membuat HDL berfungsi sebagai zat pelindung terhadap aterosklerosis, kerusakan organ karena peradangan maupun diabetes mellitus. Akan tetapi di sisi lain, diabetes mellitus dan peradangan menyebabkan penurunan konsentrasi kolesterol HDL serta mengganggu fungsi $\mathrm{HDL}^{9}$.

\section{Dampak Kolestrol HDL terhadap Kesehatan}

Metabolik yang berperan pada penyakit jantung koroner adalah profil lipoprotein aterogenik, yang dihitung menggunakan rasio kolesterol total: kolesterol HDL serta rasio kolesterol LDL: kolesterol HDL untuk memperkirakan risiko penyakit kardiovaskuler ${ }^{4}$.

Data terkini dari The Women's Health Study menunjukkan bahwa penggunaan rasio kolesterol total: kolesterol HDL merupakan prediktor risiko yang lebih kuat dibandingkan dengan hanya kolesterol LDL saja $^{13}$.

Bukti epidemiologis menunjukkan bahwa peningkatan kadar kolesterol HDL, berarti juga memperkecil rasio kolesterol total: kolesterol HDL secara bermakna.
Setiap penurunan satu unit rasio kolesterol total: kolesterol HDL, berarti mengurangi risiko infark miokard sebesar 53 persen ${ }^{13}$.

Dari hasil penelitian jantung Framingham, dilaporkan bahwa orang-orang dengan konsentrasi triasilgliserol/trigliserida tinggi (>1.7 $\mathrm{mmol} / \mathrm{L}$ ) dan kolesterol $\mathrm{HDL}$ rendah ( $<1.03 \mathrm{mmol} / \mathrm{L}$ ) mempunyai angka penyakit arteri koroner yang secara bermakna lebih tinggi daripada orang-orang dengan konsentrasi triasilgliserol rendah dan kolesterol HDL tinggi ${ }^{4}$.

Pada penelitian lain di Amerika dengan sukarelawan non-diabetes serta sehat, sebagian mengkonsumsi makanan $(A)$ yang 60 persen total kalorinya berasal dari karbohidrat, 25 persen dari lemak dan 15 persen dari protein, sementara sisanya mengkonsumsi makanan (B) yang 40 persen total kalorinya berasal dari karbohidrat, 45 persen dari lemak dan 15 persen dari protein. Secara acak, para sukarelawan mengkonsumsi salah satu dari tipe makanan tersebut selama dua minggu dengan jeda dua minggu diantaranya. Hasil penelitian menunjukkan bahwa sukarelawan yang mengkonsumsi makanan (A) dengan 60 persen karbohidrat mempunyai triasilgliserol plasma puasa, sisa lipoprotein dan sisa lipoprotein triasilgliserol lebih tinggi serta konsentrasi kolesterol HDL lebih rendah tanpa mengubah konsentrasi kolesterol LDL. Efek makanan rendah lemak ternyata tidak mencegah tingginya triasilgliserol plasma puasa serta rendahnya kolesterol HDL, tetapi juga tetap meningkatkan sisa lipoprotein. Penemuan ini menimbulkan pertanyaan para peneliti, apakah bijaksana menganjurkan seluruh warga Amerika mengganti makanan yang mengandung lemak jenuh dengan karbohidrat ${ }^{4}$.

Pengaruh asupan asam lemak jenuh pada HDL dan triasilgliserol menjadi penting terutama untuk wanita yang sudah menopause, yaitu ketika konsentrasi kolesterol HDL menurun dan risiko penyakit jantung koroner semakin besar ${ }^{14}$.

Hasil penelitian oleh Mozaffarian menunjukkan bahwa peningkatan asupan karbohidrat berkaitan dengan peningkatan perkembangan aterosklerosis. Pada populasi 
yang diteliti yaitu para wanita yang telah menopause, tingginya prevalensi dislipidemia aterogenik dicirikan dengan rendahnya kadar kolesterol $\mathrm{HDL}$ dan tingginya trigliserida (triasilgliserol). Hal ini merupakan faktor risiko yang signifikan untuk terjadinya penyakit jantung. Konsumsi makanan yang rendah lemak tetapi tinggi karbohidrat dapat memicu dislipidemia aterogenik, bila dibandingkan dengan konsumsi lemak yang lebih tinggi ${ }^{13}$.

Berdasarkan hasil penelitian yang dilakukan pada tahun 2000 untuk mempelajari faktor risiko kolesterol HDL terhadap populasi masyarakat di Tehran menunjukkan bahwa penurunan kolesterol HDL serum merupakan satu dari gangguan lipid yang paling banyak terdapat pada pasien dengan penyakit arteri koroner. Bukti yang ada menunjukkan bahwa setiap penurunan $1 \mathrm{mg} / \mathrm{dL}$ kadar kolesterol HDL serum akan meningkatkan risiko penyakit arteri koroner sebesar 2-3 persen ${ }^{15}$.

Selain perlindungan terhadap penyakit tidak menular, konsentrasi plasma kolesterol HDL juga berkaitan dengan perlindungan terhadap risiko penyakit menular dalam hal ini infeksi. Infeksi akut pada anak-anak tampaknya diiringi oleh peningkatan modifikasi LDL oksidatif dan oleh penurunan kolesterol HDL. Peredaran HDL memberikan perlindungan terhadap toksisitas endotoksin, misalnya bakteri Lipopolisakarida/LPS yang bertanggungjawab terhadap gejala patofisiologi yang mencirikan terjadinya infeksi ${ }^{4}$.

\section{Kebijakan mengenai Kolesterol}

National Cholesterol Education Program (NCEP) Adult Treatment Panel III memasukkan setidaknya tiga dari faktor risiko berikut: linggar pinggang besar, kadar trigliserida (triasilgliserol) tinggi, kadar kolesterol HDL rendah, tekanan darah tinggi serta kadar glukosa puasa tinggi secara langsung berkaitan dengan kejadian penyakit jantung koroner ${ }^{16}$.

Jika pada tahun 2001 pedoman dari National Cholesterol Education Program (NCEP) lebih mengutamakan penurunan kadar trigliserida (triasilgliserol), maka berdasarkan bukti-bukti epidemiologis dan klinis yang ada, saat ini pedoman NCEP mengalami perubahan yaitu lebih menitik beratkan pada peningkatan kadar kolesterol HDL. Saat ini dikembangkan serangkaian obat-obatan yang berpotensial meningkatkan kadar kolesterol HDL dan atau memperbaiki fungsi $\mathrm{HDL}^{17}$.

Tabel 1

Klasifikasi Adult Treatment Panel III Mengenai Kolesterol Total, Low-Density Lipoprotein (LDL) and High-Density Lipoprotein (HDL) ${ }^{18}$

\begin{tabular}{llll}
\hline \multicolumn{2}{c}{ Kolesterol Total $(\mathrm{mg} / \mathrm{dL})$} & & $\begin{array}{c}\text { Kolesterol Low Density Lipoprotein } \\
\text { / LDL (mg/dL) }\end{array}$ \\
\hline & & $<100$ & Optimal \\
\hline$<200$ & Disarankan & $100-129$ & $\begin{array}{l}\text { Mendekati optimal/di atas } \\
\text { optimal }\end{array}$ \\
\hline $200-239$ & Garis batas tinggi & $130-159$ & Garis batas tinggi \\
\hline \hline 240 & Tinggi & $160-189$ & Tinggi \\
\hline
\end{tabular}




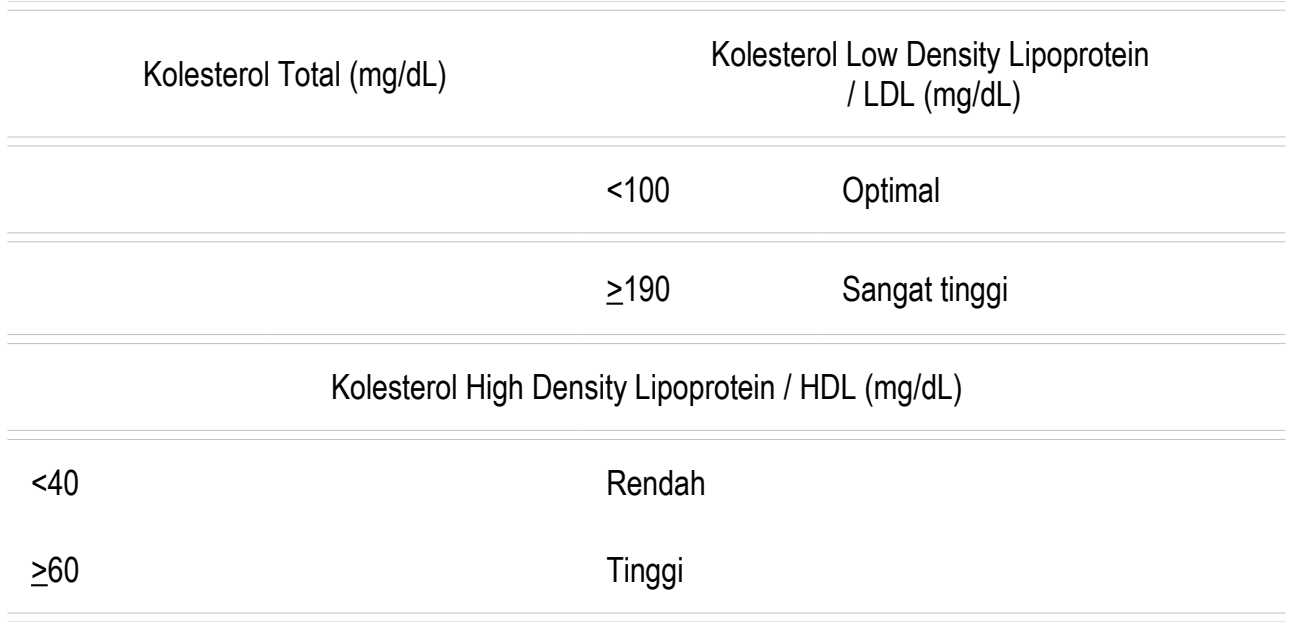

Rekomendasi Adult Treatment Panel III of NCEP tahun 2001, diperbaharui pada tahun 2004 guna merefleksikan ilmu pengetahuan dari lima percobaan klinis yang hasilnya dikeluarkan tahun 2005. Rekomendasi utamanya yaitu ${ }^{19-22}$ :

1. Pada orang yang berisiko tinggi, target kadar kolesterol LDL <100 $\mathrm{mg} / \mathrm{dL}$, tetapi jika risiko sangat tinggi target kadar kolesterol LDL $<70 \mathrm{mg} / \mathrm{dL}$.

2. Target kadar kolesterol HDL $>40$ $\mathrm{mg} / \mathrm{dL}$ (untuk laki-laki) dan $>50 \mathrm{mg} /$ $\mathrm{dL}$ (untuk perempuan).

3. Target kadar trigliserida $<150$ $\mathrm{mg} / \mathrm{dL}$.

4. Target kolesterol non-HDL $130 \mathrm{mg} /$ $\mathrm{dL}$ pada kasus hipertrigliseridemia.

5. Fibrat efektif dalam menurunkan trigliserida dan meningkatkan kadar HDL.

6. Statin efektif menurunkan kadar LDL.

7. Fibrat dan Statin sangat efektif dalam mengontrol abnormalitas profil lipid pada pasien dengan sindrom metabolik.

Berdasarkan bukti yang ada, Panel Konsensus Eropa merekomendasikan target minimum kolesterol HDL sebaiknya 40 $\mathrm{mg} / \mathrm{dL}(1,03 \mathrm{mmol} / \mathrm{L})$ pada pasien dengan penyakit jantung koroner atau yang berisiko tinggi menderita penyakit jantung koroner, termasuk pasien yang mempunyai risiko tinggi terhadap diabetes tipe 2 atau sindrom metabolik ${ }^{23}$.

Bahan Makanan Alami Peningkat Kadar Kolesterol HDL

Berdasarkan penelitian Mursu et $\mathrm{al}^{24}$ pada partisipan sehat dan bukan perokok, ditemukan bahwa dark chocolate dan dark chocolate yang diperkaya dengan cocoa poliphenol mampu meningkatkan konsentrasi kolesterol HDL sebesar 11,4-13,7 persen serta menurunkan konsentrasi LDL serum sebesar 11,9 persen.

Berdasarkan penelitian, diketahui proporsi peningkatan konsentrasi kolesterol HDL plasma dihasilkan oleh asam lemak jenuh. ${ }^{25}$ Bukti yang dapat dipertimbangkan menunjukkan bahwa asupan lemak jenuh mendukung peningkatan metabolisme HDL. Adalah ironis bahwa makanan yang kaya akan lemak jenuh dan kolesterol tidak hanya meningkatkan konsentrasi kolesterol LDL tetapi juga meningkatkan konsentrasi kolesterol HDL, terutama makanan yang mengandung lemak keturunan asam laurat dan miristat dalam jumlah besar".

Dari hasil penelitian epidemiologis pada negara-negara yang menggunakan minyak kelapa (yang mengandung asam lemak jenuh sebesar $92 \%$ ) dalam makanan harian mereka, yaitu negara-negara di Asia seperti Sri Lanka, India, Filipina, Indonesia dan pulau-pulau di Pasifik Selatan (tidak termasuk konsumsi minyak kelapa Amerika 
yang hanya 0-2 persen dari asupan kalori) menunjukkan bahwa kadar kolesterol serum dan angka kematian serta kesakitan akibat penyakit jantung koroner rendah. Sementara dari penelitian Mendis, Wissler et al terhadap remaja pria di Sri Lanka di mana mereka mengganti kebiasaan mengkonsumsi minyak kelapa dengan minyak jagung, diperoleh hasil bahwa ketika mereka mengkonsumsi minyak kelapa kadar kolesterol HDL cenderung meningkat dan menurunkan rasio LDL : HDL dibandingkan ketika mereka mengkonsumsi minyak jagung ${ }^{26}$. Selain itu, menurut Soerjodibroto ${ }^{27}$ kandungan EPA (eicosa pentaenoic acid) dan DHA (docosa hexaenoic acid) dalam minyak kelapa terbukti dapat menurunkan kadar very low density lipoprotein (VLDL).

\section{SIMPULAN}

1. Kolesterol HDL berperan dalam membalikkan transport kolesterol yang memungkinkan organ hati untuk membuang kelebihan kolesterol dalam jaringan perifer, sehingga mencegah terbentuknya aterosklerosis yang merupakan penyebab penyakit kardiovaskuler.

2. Peran kolesterol HDL ini juga mencegah kelebihan jaringan lemak yang dapat menurunkan sensitivitas insulin, dengan demikian insulin dapat bekerja secara normal sehingga mencegah penyakit diabetes mellitus.

3. Selain itu keberadaan kolesterol HDL dalam tubuh akan memberikan perlindungan terhadap toksisitas endotoksin, misalnya bakteri Lipopolisakarida/LPS yang bertanggungjawab terhadap gejala patofisiologi yang mencirikan terjadinya infeksi.

4. Penurunan $1 \mathrm{mg} / \mathrm{dL}$ kadar kolesterol HDL serum dapat meningkatkan risiko penyakit arteri koroner sebesar 2-3 persen. Penurunan satu unit rasio kolesterol total : kolesterol HDL berarti mengurangi risiko terjadinya infark miokard sebesar 53 persen.
5. Rendahnya kadar kolesterol HDL merupakan faktor risiko paling kuat untuk terjadinya aterosklerosis pada penderita diabetes mellitus tipe 2 . Penyebab penyakit kardiovaskuler ini (aterosklerosis), merupakan penyebab utama morbiditas dan mortalitas pada penderita diabetes mellitus tipe 2 .

6. Peningkatan konsentrasi kolesterol HDL plasma dihasilkan oleh asupan asam lemak jenuh, terutama yang mengandung asam laurat dan miristat. Bahan alam yang dapat meningkatkan konsentrasi kolesterol HDL adalah Dark Chocolate (coklat hitam/pekat) baik yang diperkaya dengan Cocoa Polifenol ataupun tidak, serta Minyak Kelapa.

\section{RUJUKAN}

1. Badan Litbangkes. Riset Kesehatan Dasar Indonesia 2007. Jakarta: Badan Penelitian dan Pengembangan Kesehatan. 2008.

2. Rustika. Peran keluarga terhadap penurunan faktor-faktor risiko penyakit jantung di daerah MONICA Jakarta. Kumpulan Makalah Seminar Sehari Presentasi Hasil MONICA Jakarta. Pusat Jantung Nasional Rumah Sakit Jantung dan Pembuluh Darah Harapan Kita. Jakarta. 2002;1-10.

3. Supari F. Profil lipid plasma pada MONICA III tahun 2000. Kumpulan Makalah Seminar Sehari - Presentasi Hasil MONICA Jakarta. Jakarta: Pusat Jantung Nasional Rumah Sakit Jantung dan Pembuluh Darah Harapan Kita.. 2002;1-17.

4. German JB \& Dillard CJ. Saturated fats : What dietary intake? Am J Clin Nutr. 2004;80:550-9.

5. Thomsen $\mathrm{C}$, Storm $\mathrm{H}$, Holst JJ, Hermansen K. Differential effects of saturated and monounsaturated fats on postprandial lipemia and glucagon-like peptide 1 responses in patients with type 2 diabetes. Am J Clin Nutr. 2003;77:605-11. 
6. Temelkova-Kurktschiev T, Hanefeld M. The lipid triad in type 2 diabetes and relevance of hypertriglyceridaemia/low high-density lipoprotein syndrome in type 2 diabetes. Exp Clin Endocrinol Diabetes. 2004;112(2):75-9.

7. Krauss RM, Blanche PJ, Rawlings RS, Fernstrom HS, Williams PT. Separate effects of reduced carbohydrate intake and weight loss on atherogenic dyslipidemia. Am J Clin Nutr. 2006;83:1025-31.

8. Silalahi J. Hypocholesterolemic factors in food: A review. Indonesian food and nutrition progress. 2000;7(1):26-35.

9. Rohrer $L$, Hersberger $M$, von Eckardstein A. High Density Lipoproteins in the Intersection of Diabetes Mellitus, Inflammation and Cardiovascular Disease. Curr Opin Lipidol. 2004;15(3): 269-78.

10. Von Eckardstein A, Hersberger $M$, Rohrer L. Current understanding of the metabolism and biological actions of HDL. Curr Opin Clin Nutr Metab Care. 2005;8(2):147-52.

11. Norata GD, Catapano AL. Molecular Mechanisms for the Antiinflammatory and Protective Effect of HDL on the Endothelium. Vasc Health Risk Manag. 2005; 1(2): 119-29.

12. Montoya MT, Porres A, Serrano S, Fruchart JC, Mata P, Gerique JAG, et al. Fatty acid saturation of the diet and plasma lipid concentrations, lipoprotein particle concentrations and cholesterol efflux capacity. Am J Clin Nutr. 2002;75:484-91.

13. Griel AE, Kris-Etherton PM. Beyond saturated fat: The importance of the dietary fatty acid profile on cardiovascular disease. Nutr Rev. 2006;64(5): (I)257-262

14. Mozaffarian D, Rimm EB, Herrington DM. Dietary fats, carbohydrate, and progression of coronary atherosclerosis in postmenopausal women. Am J Clin Nutr. 2004;80:1175-84.
15. Azizi $F$, Raiszadeh $F$, Salehi $P$, Rahmani M,Emami $H$,Ghanbarian $A$, et al. Determinants of serum HDL-C level in a Tehran urban population : the Tehran lipid and glucose study. Nutr Metab Cardiovasc Dis. 2002;12(2):80_ 9.

16. Vinik Al. The metabolic basis of atherogenic dyslipidemia. Clin Cornerstone. 2005;7(2-3):27-35.

17. Gotto AM Jr. High-density lipoprotein cholesterol and triglycerides as therapeutic targets for preventing and treating coronary artery disease. Am Heart J. 2002;1446(6 Suppl):S33-42.

18. National Cholesterol Education Program Adult Treatment Panel III. 2004 [cited 2009 Mar 29]. Available from: http://www.guideline.gov/summary/sum mary.aspx? ss=15\&doc id=5503\&nbr=3746\#s23

19. Grundy SM, Cleeman JI, Merz CN, Brewer HB Jr, Clark LT, Hunninghake $\mathrm{DB}$, et al. Implication of recent clinical trials for the National Cholesterol Education Program Adult Treatment Panel III guidelines. Arterioscler Thromb Vasc Biol. 2004;24(8):e149—61.

20. Moon YS, Kashyap ML. Pharmacologic treatment of type 2 diabetic dyslipidemia. Pharmacotheraphy. 2004;24(12):1692-713.

21. Ferdinand KC. Management of cardiovascular risk in patients with type 2 diabetes mellitus as a component of the cardiometabolic syndrome. J Cardiometab Syndr. 2006;1(2):133—40.

22. Ascaso J, Gonzales SP, Hernandez MA, Mangas RA, Masana L, Millan J, et al. Management of dyslipidemia in the metabolic syndrome : recommendations of the Spanish HDL-forum. Am J Cardiovasc Drugs. 2007;7(1):39—58.

23. Chapman MJ, Assmann G, Fruchart JC, Shepherd J, Sirtori C. Raising highdensity lipoprotein cholesterol with reduction of cardiovascular risk : the role of nicotinic acid-a position paper 
developed by the European Consensus Panel on HDL-C. Curr Med Res Opin. 2004;20(8):1253-68.

24. Mursu J, Voutilainen S, Nurmi T, Rissanen TH, Virtanen JK, Kaikkonen J, et al. Dark Chocolate Consumption Increase HDL Cholesterol Concentration and Chocolate Fatty Acids May Inhibit Lipid Peroxidation in Healthy Humans. Free Radic Biol Med. 2004;37(9):1351-9.

25. Hu FB, Stampfer MJ, Manson JE, Ascherio A, Colditz GA, Speizer FE, et al. Dietary saturated fats and their food sources in relation to the risk of coronary heart disease in women. Am J Clin Nutr. 1999;70:1001-8.

26. Dayrit C. Coconut Oil : Atherogenic or Not? Philippine Journal of Cardiology. 2003;31(3): 97-104.

27. Soerjodibroto W. Lemak dalam Pola Makanan Masyarakat Indonesia dan Masyarakat Kawasan Asia Pasifik Lainnya : Hubungannya dengan Kesehatan Kardiovaskuler. [Ph.D thesis] Jakarta: Fakultas Kedokteran Universitas Indonesia; 2005. 